\title{
4）病院・国内でのChoosing wisely導入と教育活動
}

\author{
群星沖縄臨床研修センター 徳田 安春
}

Choosing wiselyキャンペーンの目的は, 医師 と患者の対話を促進することで, エビデンスに 基づく医療介入の実践を広げることである，活 動の原点は, 医師のプロフェッショナリズムで ある. 先進国を中心として, 2018 年 8 月時点で は約 20 カ国に広がっているのは, 先進国に共通 する重要な課題に, 医療介入に過剩な部分があ るからである。キャンペーンで発信されるメッ セージは, 各国の主要な臨床系の医学会や団体 が自発的に発表したものである.「5つのリスト」 と呼ばれる $5 つ の$ 簡潔な単一文の提言は理解し やすく記憶されやすいため, 広がりやすい知識 となっている. 感染症分野での薬剤耐性問題に 関連するChoosing wiselyの提言については, 抗 微生物薬の適正使用を促すよう, 世界各国の学
会から発信されている。代表なものとしては, 急性上気道炎に対する抗菌薬投与は避けるべき である, 適切に切開排膿された皮虐膿瘍に対す る抗菌薬投与は避けるべきである等の提言があ る. 日本においてもChoosing Wisely Japanが活 動を開始し, 日本医学会においてもChoosing wiselyの公開シンポジウムが開催され,さまざま な団体から自発的に作成した提言が発信されて いる. そのなかには, 抗微生物薬の適正使用を 促すものもある. 今後は, 日本の主要な臨床系 の学会が自発的に提言を作成し，発表すること が期待されている. 日本の内科医もChoosing wiselyの提言内容を理解し, 患者との対話に活用 することによって，エビデンスに基づく医療介 入の実践を行いやすくなるであろう.

\section{5）開業医での抗菌薬適正使用実践例}

\section{まえだ耳鼻咽㑨科クリニック 前田 稔彦}

多くのクリニックでは看護師等の確保に苦労 し，パート職員に支えられていることが多く， 患者は職員らとより身近な関係にある。抗菌薬 の使用においては, 科学的な根拠がそしいなか で経験や勘に頼ることや, 患者からの抗菌薬処 方の強い要望に応え, 抗菌薬を処方せざるを得 ない場合もある、私たちは, 感染症治療に関係 するこれらの問題点を克服するために, 診療に グラム染色を導入し, 簡便・迅速に原因菌を推 定し, 適切な抗菌薬を選択するための取り組み を続けている。本講演では, この取り組みの概 要と成果について述べる.

行程としては, (1) 患者の臨床検体を医師が
採取する（2）グラム染色をメディカルスタッ フが実施する，（3）顕微鏡観察を行う，（4）検 体の部位と顕微鏡像に基づき, 推定起因菌と選 択されるべき抗菌薬を薬殽師が医師に提案する という順番・分担で, 各職種が連携しながら進 められる。検体採取から処方提案までに要する 時間は約 5〜10 分である. さらに, 服薬指導で は, 患者にグラム染色像を開示しながら, 推定 される起因菌の種類やなぜ抗菌薬が処方された (されなかった)のかという説明を行う。この取 り組みを過去 14 年間に亘り, 延べ 14,000 人以上 の患者に実施した結果, 実施前と比較し, 抗菌 薬の処方件数は約 7 分の 1 に減少した. 一方で, 